\title{
Optimal Structure of Pension System and Its Influence on the Social Policy of State Budget
}

\author{
Marina Tabatadze \\ Ivane Javakhishvili Tbilisi State University, Georgia, tabatadze_marina@yahoo.com
}

\begin{abstract}
The world is witnessing an important increase in number of elderly people. This process is accompanied by the increase of the proposition of working and retired population, which has significant economic, social and political implications. To answer these challenges, the governments across the world engaged in comprehensive reforms of social policies, out of which the reform of pension system is the most important. The presented research aims to determine the main directions of pension reforms undertook by different countries. More precisely, the objective is to identify the trends characterizing reforms in developing countries and compare them to the tendencies observed in the reforms of developing economies. Therefore, the aim of research is to get generalized results, which will contribute greatly to the existing scientific literature and will be useful in the process of perfecting and improving the current pension reform. To do so, the paper studies reforms together with the existing scientific literature and public reports issued by international organizations. The results of the study suggest that the most common pension system across the globe implies introduction of the accumulated pension model (Defined Contribution Plan) instead of solidarity pension scheme (Defined Benefit Plan). This is a radical change impacting country's economy, social and cultural norms and legislation. The reason behind the reform was the limitation of the existing model, but also the demographic trend of aging the population.
\end{abstract}

KEYWORDS: Pension reforms, retirement, public policy, state budget, Defined Contribution Plan

\section{Introduction}

Changing demographic situation is one of the common problems across the globe, reaching out for both, developed and developing economies. The number of the world's older persons is supposed to increase by $56 \%$ in next ten years. The increase in number of elderly people will be accompanied by the increase of the proposition of working and retired population, which will have significant economic, social and political implications. To answer these challenges, the governments across the world engaged in comprehensive reforms of social policies, out of which the reform of pension system is the most important (Lee \& Mason, 2010). The objective behind these reforms is to prolong the labour force participation in older persons' incomes and improve the financial sustainability of pension systems by introducing more merit and personal input-based schemes.

The Georgian government undertook important reforms in this direction since 2017, defining the existing system old-fashioned, unjust and unsustainable. The proposed modification implies the change of the Defined Benefit Plan (DB) into the Defined Contribution Plan (DC). In other words, solidarity elements of the pension fund will be replaced by the mandatory contribution from the working class. Despite the general consensus in the society and number of researches pointing out that the current pension system cannot be sustainable in a long term, the new draft law received important criticisms from different social groups.

The introduction of the accumulated system reduces the state's social expenditures and contributes to the equal distribution of monetary resources, but it is also considered to be delicate to calculate and manage. Number of governments in developing economies consulted scientific researches while elaborating new pension policies. As the topic is particularly new in Georgia, there is no scientific research in this direction. The aim of the present research paper is to fill in the gap in scientific literature with an empirical illustration of pension reform in post-soviet economies. More precisely, the aim is to conduct an important empirical study in Georgia, in order to elaborate a theory on an optimal pension scheme in developing economies.

Pension reform is a highly sensitive issue and determines the socio-economic and political will of a nation. The particularity of this type of research is that number of stakeholders have a key role: government private sector organizations, the population. This shows its high social 
responsibility. This makes the research particularly vulnerable and implies number of risks (Bovenberg \& Nijman 2017). The major hazard of the research is the difficulty to reach out for all these stakeholders. Due to the scale of the research topic, it is particularly difficult to cover the whole spectrum of the data that needs to be studied. Each stakeholder oversees the pension reform from his point of view and thus, gives additional challenge to the research team to thoroughly reflect the social reality. The challenge is also to make sure that the research outcomes correspond to the country's strategic direction and priorities ("Georgia 2020").

First, we will review the global trends of pension reform across the globe. Particular attention will be paid to the European experience, as, since the Association Agreement with the EU, Georgia follows closer the European guidelines in socio-economic regulations. Secondly, we will review the Georgian reform and give some recommendations on its optimal implementation.

\section{Global trends of pension reforms}

According to the World Population Prospects by the United Nations the number of older persons (those aged 60 years or over) has increased considerably in recent years in most countries and this growth is projected to even accelerate in the coming decades (United Nations 2015). Between 2015 and 2030, the number of people in the world aged 60 years or over is supposed to grow by 56\%, from 901 million to 1.4 billion, and by 2050, the global population of older persons is projected to more than double its size in 2015 , reaching nearly 2.1 billion.

Growth in the numbers and proportions of older people can be expected to have far-reaching economic, social and political implications (Kingsley 2015). This trend leads governments across the globe to consider number of reforms: economic, social... Important efforts are paid to increasing the statutory ages at retirement in order to prolong the labour force participation of older persons' incomes and improve the financial sustainability of pension systems by introducing more merit and personal input-based schemes (Bijak et al. 2007).

The issue of transformation of the pension system is critical in modern world, giving double objectives to governments. On the one hand, new pensions systems should balance the distribution of revenue and, on the other hand, it must provide a decent old age retirement to the population. Inefficiency of the state pension funds, their unsustainability and the ever-increasing deficits show that a full-scale social security of the retired population is not possible only through a solidarity model of pension system. Thus, governments across the world started reforming their pension systems since few decades.

States and economists are facing a challenge to elaborate a pension structure which will allow both, solve the misbalance between the revenue sharing and, at the same time, satisfy the need of all stakeholders (Arnberg \& Barslund 2012; Kochskaemper 2015). To do so, it is vital to identify the needs and interests of each stakeholder and transform the pension system accordingly. Plus, this transformation should be done in accordance with the state's general fiscal policy (Tabatadze 2016a).

Great part of the world has reformed its pension system. Most of European Union states use their own model (Blanchet, Bozio \& Rabaté, 2016). We can list specific models created in Belgium, France or Malta. Some states do not have specific models but their pension schemes were elaborated according to the particular socio-economic systems of the country, i.e. Finland, Germany. The table 1 shows 44 modelling instruments applied by administrations of 26 Member States. 
Table 1: Pension modelling instruments applied by governments of EU States

\begin{tabular}{|ll|}
\hline UE State & Pension model \\
\hline Austria & Austrian Applied Projection Models; Austrian Microsimulation Model \\
\hline Belgium & MALTESE; MEP; MIDAS_BE; MIMOSIS \\
\hline Bulgaria & ILO PENS (BG) \\
\hline Cyprus & Cyprus ILO PENS (CY) \\
\hline $\begin{array}{l}\text { Czech } \\
\text { Republic }\end{array}$ & Czech Pension Model \\
\hline Denmark & Danish Pension Model; LAW \\
\hline Estonia & Estonian Long-Term Pension Budget Model \\
\hline Finland & Finnish Centre for Pensions models \\
\hline France & DESTINIE; PRISME \\
\hline Germany & AVID; German Pension Model \\
\hline Greece & Greek Pension Model \\
\hline Hunbce & Hungary Hungarian Pension Models; NYIKA \\
\hline Ireland & Irish Pension Model \\
\hline Italy & Italy CAPP_DYN; CeRP models; RGS \\
\hline Latvia & Latvia Latvian Pension Model \\
\hline Lithuania & PRISM \\
\hline Luxemburg & Luxemburg LuxMod; REDIS; SOBOLUX \\
\hline Malta & PROST (MT) \\
\hline Netherlands & Netherlands GAMMA; MICROS; SADNAP \\
\hline Poland & FUS07 \\
\hline Portugal & ModPensPor \\
\hline Slovakia & PROST (SK), MAJA \\
\hline Slovenia & SIOLG 1.0 \\
\hline Spain & Spain Spanish Pension Model \\
\hline Sweden & MiMESIS, SESIM \\
\hline $\begin{array}{l}\text { United } \\
\text { Kingdom }\end{array}$ & PENSIM2 \\
\hline
\end{tabular}

It is common for states to use another country's pension scheme as a model for adapting it for their own needs. We can list, for example, Portugal, where ModpensPor, a cohort-based standard simulation model has been adapted by the Cabinet for Strategy and Planning (GEP) of the Portuguese Ministry of Labour and Social Solidarity from Spain's Modpens model (developed by Fundación de Estudios de Economía Aplicada) with the help of an external contractor in 1996.

Despite differences per country, the general idea behind the world reforms is to replace solidarity schemes with an accumulated pension model. Great Britain, Sweden, Germany and Italy have partially privatised their pension funds; France has profoundly renovated its Pay-as-you-go scheme; Hungary and Poland opted for hybrid schemes where traditional pensions systems are to be replaced by mandatory saving systems (Tabatadze 2016b). Reforms focused partly on reducing spending and on ensuring poverty prevention through generous indexation of minimum benefits. Some of them opted by default or by choice for flat, universal benefits, sometimes complemented by savings pillar. General emphasis for all of them is tightly linking contributions to benefits.Most common pension system of recent reforms is accumulated pension scheme (Cipriani 2018). There is no universal model of this system, giving each state a choice to adapt it to its national characteristics (Devolder \& Valeriola 2018). It is advised that while reforming its pension system, 
state should take into account the national characteristics (demographics, social-economic, historic, cultural and legislative) and the experience of foreign countries. It is important to consider the local legislation in accordance with international standards. That is why reforming a pension system is particularly difficult and rigorous process which requires inclusion of the population (Anderson \& Pratt 2016).

The second pillar of the new pension models vary per country. The figure 1 demonstrates that countries which recently reformed their pension systems opted for different percentage for the second pillar, going from 2 to 16 percent.

Figure 1. Second pillar volume across countries

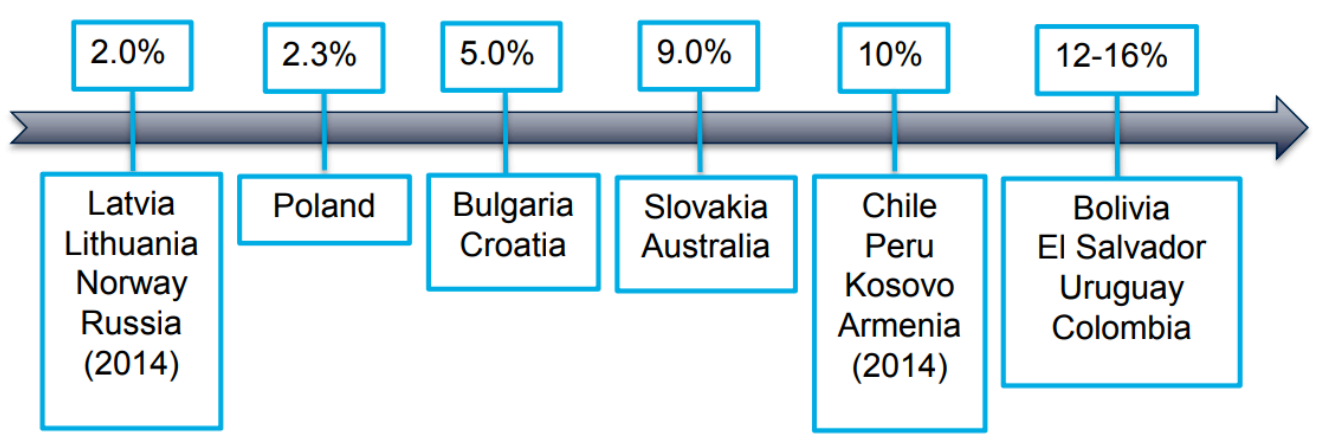

In terms of the approaches of administrations to pension modelling, countries from the EU can be grouped in two categories: countries using microsimulation models and countries using standard models. The table 2 proposes this differentiation.

Table 2: Classification of administrations according to modelling pensions

\begin{tabular}{|l|l|l|}
\hline Exclusive use of standard models \\
\hline \multirow{2}{*}{} & Imported models customised to special needs & $\begin{array}{l}\text { Bulgaria, Cyprus, Latvia, Lithuania, Malta, Portugal, } \\
\text { Slovakia (MoF) }\end{array}$ \\
\cline { 2 - 3 } & Own developments \\
\hline & No steps toward microsimulation & $\begin{array}{l}\text { Estonia, Greece, Ireland, Poland, Slovakia (MoLSAF) } \\
\text { Slovenia }\end{array}$ \\
\cline { 2 - 3 } & Steps toward microsimulation & Czech Republic, Spain, Hungary, Austria \\
\hline Utilisation of microsimulation models \\
\hline
\end{tabular}

\section{Georgian case of pension scheme modernization}

Georgia is currently undergoing important reforms of pension system. In last decades Georgia has been through multiple rounds of pension reforms. The first important was the introduction of a flat rate pension in 1995. Another important reform of the pension system commenced in 2004. Until 2004, state pensions were financed by the State United Social Insurance Fund (SUSIF) based on social contributions of employer and employee. From 2004, social programs became financed from the general budget revenues. From 2008 to 2012, the pension amount included a long-service bonus distributed on top of the flat rate pension - for those with 25 years or more of working life, the bonus was GEL 10 per month. At the end of August 2012, pensioners stopped receiving long-service bonuses and instead received the combined amount as a flat rate pension benefit.

In October 2017, the government announced its plan for a new reform. The Ministry of Economy and Sustainable Development of Georgia ("MOESD") created a Pension Reform Unit ("PRU") with ultimate goal to design a pension reform strategy, which proposed mechanism for 
increasing the social pension (indexation) and the creation of a complementary pension system component - the contributory private pension model and prepare the relevant draft law on contributory pension model.

Georgia's current pension system is limited to a public basic universal flat-rate pension for everyone living in Georgia at the moment of reaching the retirement age. The retirement age is 65 years for men and 60 years for women. The system consists of two, unbalanced parts: on the one hand there is a state pension fund, which is the major source of pension and is part of state expenditure; and a private pension system which only covers unimportantly little part of the market and does not have the necessary legislative bases for further development. The government spends $4,3 \%$ of GDP on the financing of pensions.

Georgia's demographic situation coincides with the global trend and shows declining working age population and increasing elderly people. There is also a projection that the overall population is also expected to decline from 4,5 million to 3,8 million by 2080 as illustrated in the figure 2 .

Figure 2. Projected population change in Georgia

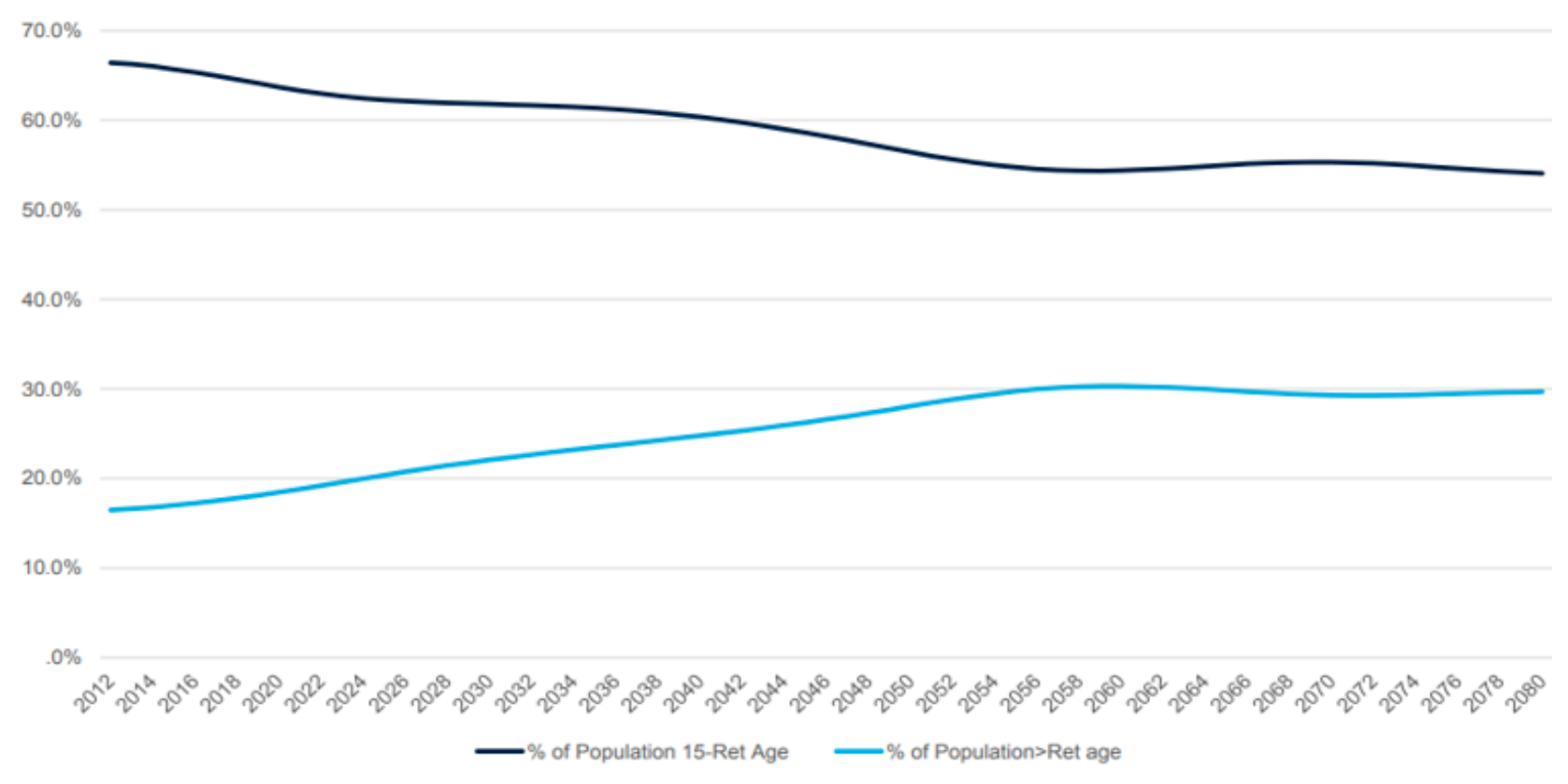

Source: World Bank Group, 2016, working paper series

The state's expenditure on social services is constantly increasing. The part of spending on pension increased by $71 \%$ in last decade. The number of retired populations is to be doubled (OCED 2015c). State budget fund only includes the income tax of the part of the population, employed in format sector (Schwan \& Sail, 2013). Self-employed, grantees, employees of international organisations and many others, do not contribute. In 2015 1,8 million people were officially employed (or were actively looking for employment) out of 2 million working age population. However only 753000 were employed for more than 6 months, resulting in an important social charge for the state budget. According to recent estimations, the state budget won't be able to cope with the demand in only one decade (Tkemaladze 2016b).

The current pension system is also criticized for being unfair as the pension is paid out to everyone, regardless their employment record, residence in Georgia during their active lives and paid taxes and other incomes or financial resources. Another criticism claims that the existing system constitutes an incentive to informal work due to its law rate (Tabatadze, et al., 2008). Last, the current system does not give the possibility of early retirement (for some professions).

To answer these challenges, the Georgian government initiated a new low in October 2017 which was promulgated in July 2018. The new low proposes a hybrid semi-mandatory pension savings ("Defined Contribution - DC") scheme. Georgia's libertarian ideology minimizes and even 
belittles the concept of social responsibility, advocating instead a system based on personal responsibility. The proposed scheme is mandatory for employees under 40 years of age from the July the $1^{\text {st }} 2018$ and onwards. Workers over 40 years of age would be auto-enrolled but would the option to opt-out during only 5 months after enrolment. Self-employed could join the scheme on a voluntary basis.

Some criticisms were announced in regards with the new reform. Some fear that "hundreds of thousands of Georgian citizens will remain without a decent pension in the future", qualifying the government's proposal as a possible threat of massive old-age poverty among the population (Hutsebaut 2017). Others think that the new law does not define the regulation and control mechanism on the legal entities included in the pension system (Tkemaladze 2016a). There is actually no clear definition of legal statuses of different institutions which can manage the pension funds. Nothing is said about their structure and governance forms either. Neither is there any mentioning of an eventual 3rd pillar pension (occupational or personal DC scheme).

Another criticism demonstrated that the introduction of Pay As You Go Systems, as a part of generous spending, is unaffordable for lower spending transition economies. The figure 3 shows the position of Georgia in comparison with other EU states per income and spending on pension.

Figure 3. European Union counties pension spending per income level

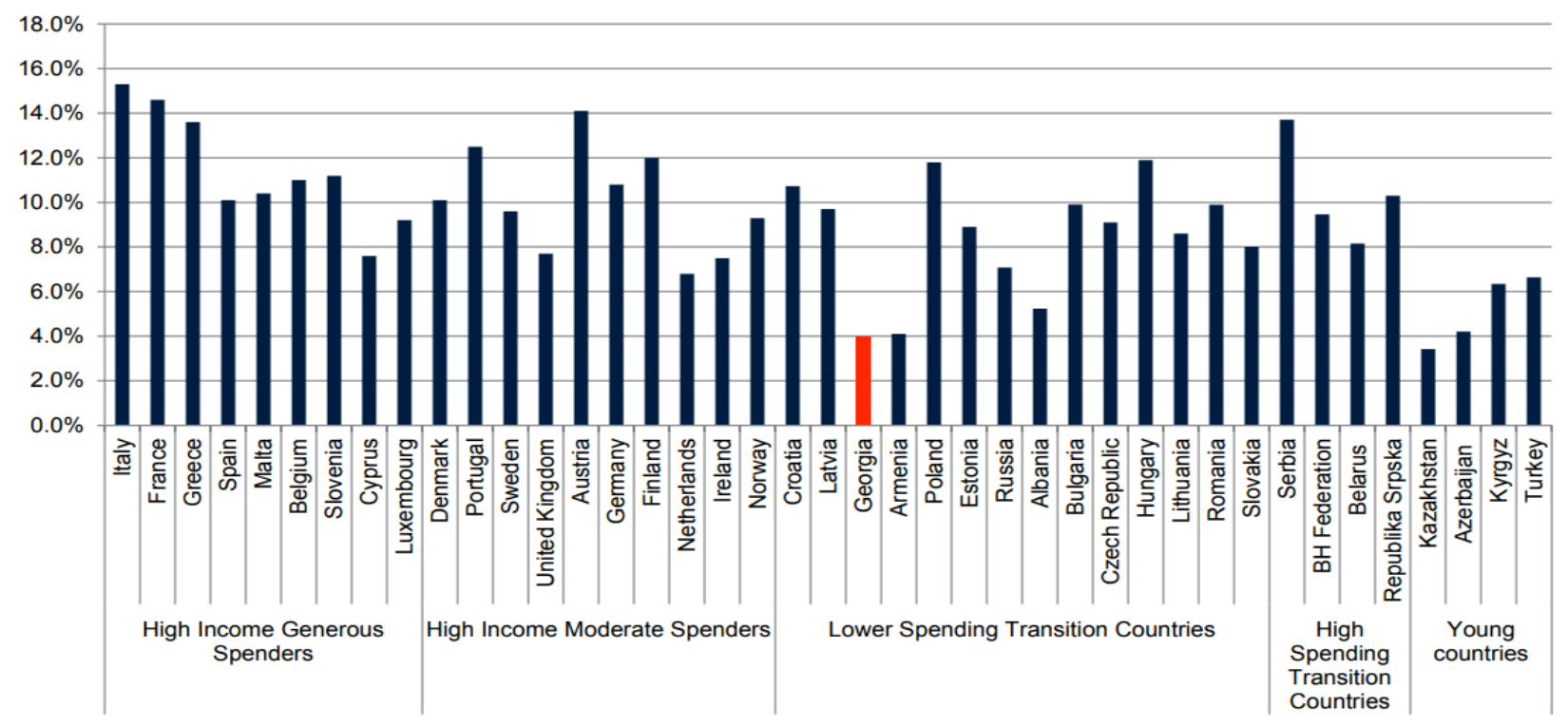

The reform can also be critisised as purely voluntary systems usually have relatively low coverage, rarely exceeds $15-20 \%$. The coverage mostly reaches better off, formally employed people and demonstrates a poor segmentation. Even this scenario requires generous tax benefits, because, as witnessed in other countries, it almost never works without benefits (World Bank 2016). See figure 4 for some examples. 
Figure 4: Voluntary and mandatory pension savings as a perntage of GDP in some countries

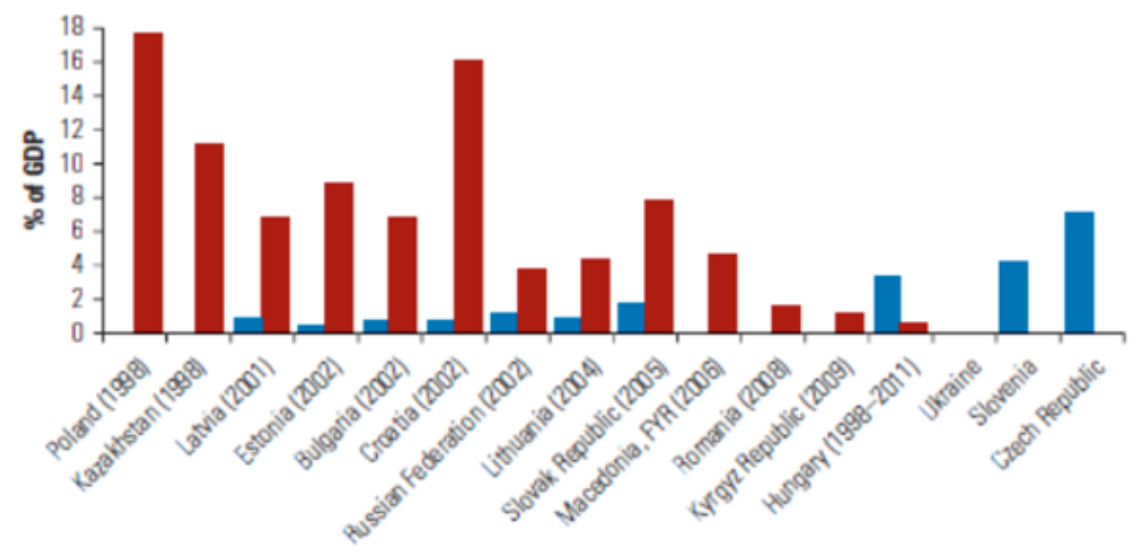

Source: The Inverting Pyramid, The World Bank, 2014

Retirement reform represents an instrument of the social benefit program, which helps the pensioners in need but cannot necessarily guarantee and provide the living minimum. Based on that, it is essential to take actions for the retirement system to become an effective mechanism. For these actions to be successful, the Georgian government as well as governments of similar states can consider following recommendations

\section{Recommendations}

Recommendations can be made to the content of the law as well as the way it was implemented. One of the main issues of this reform was the mis or lack of communication between the reformers and the population. The users were not given the full information about the essence of the reform which arouse number of misinterpretations, followed by a negative attitude towards the reform. This is very sensitive topic for Georgia. During the collapse of the Soviet Union people, who had some savings at the bank and other financial institutions, lost all of their money overnight. Even if this was over 30 years ago, the level of trust to government has not been improved since then. That is why, a clear and conscience communication is even more important for the case of Georgia. We would recommend the reformers to communicate with all social classes and all stakeholders with tailored messages.

Lack of communication is directly linked with the issue of transparency. As of today, the pension fund created with the reform is not definitely structured, which increases the doubt among the population. People are afraid that an unstructured organisation cannot perform well. This is particularly important as people started contributing to the retirement fund, while the fund has no responsible assigned yet. Lack or hierarchical superior is considered as a lack of responsible person if something goes wrong. The relations between the fund and the responsible governmental organisation should be more transparent as well. One concern the population expressed is what happens, or who will be responsible, if the fund goes bankrupt.

One more recommendation at the impelmentation level can be the use of RIA methodology in order to minisie the rists. Association Agreement with the European Union proposes Georgia analyse their reforms using RIA tool. However, the pension has not opted for this possibility. Control has to be done yearly or quarterly and should include all stakeholders from the government.

As for the contents of the reform, the government should pay particular attention and encourage voluntary participation of self-employed and hired employees who remain outside the pension reform. Private companies should be given proper support and stimulus to increase their awareness level so that they become important players in the pension market.

To encourage the involvement in the accumulating retirement scheme, the government can work on the taxation benefits (these benefits should also consider the cases involving engagement of the private retirement system). The fairness of the optional retirement system is proven by the fact that relying on the research of "Dependency of the population regarding the retirement system", 
$65 \%$ of the population supports the optional retirement scheme. Encouragement can also be brought in the way of special financial stimulation, and informing the population regarding the offered scheme.

One of the ways to achieve the declared goals of the Government and to increase participation in the new pension system is to revise the age limit (40 years) for the obligatory participation. The proposed initiative cannot provide the so-called "Dignified Pension" because only 25\% of the working population is employed, $34 \%$ are self-employed and $41 \%$ are unemployed or they are not included in working population. It should be taken into consideration that $58.4 \%$ of the employed people are over 40 years old and are not obliged to involve in the pension scheme. As a result, it turns out that compulsory accumulation pension system will cover only $10.5 \%$ of the working population. There is no possibility of taking a "decent pension" with low wages. The average salary for employed people is 1000 GEL per month.

To improve the retirement rate, the differentiated deposit rates should be negotiated and at the same time, the future (predicted) economic growth of the country should be included. To avoid the temporary shocks on the labor market, it is important to deeply analyze and study the specifics of the deposit rates.

The state budget is added to a significant burden (1-2\% taxation in the pension scheme). In the background, the current retirement pension costs are kept in the budget and in the 20-30 years only with a low pace increase (retaining a monthly to the best international practice, the reduction of fiscal risks by pension of 180 pounds), considering today's social background and the political context we find it impossible according accumulating pension system has led to a slowdown in social pensions, which has not been declared by the government.

The proposed pension system promotes social inequality in the state population. In the future, employed and high-income citizens will more or less contribute to pensions than unemployed and low-income populations. In other equal terms, social inequality in the retirement age will increase.

For developing countries like Georgia, it is essential that a large portion of the pension fund's resources be placed in local assets in order to develop the local capital market. However this should be done with economic instruments as not legislative. The government should be prohibited by law to coercive interference with the pension fund for various political purposes. The safe and efficient management of the contributions of participants in the new pension system is essential to the existence of a strong mechanism against the crisis and other negative external factors.

\section{Conclusion}

Reforming a pension system is a long, difficult and problematic issue, with significant social and political implications. It aims at rational distribution opportunities, optimization of budget expenditures, and balancing the country's social policy development strategy. It is important to properly plan the stages of the preparation of the reform, evaluate all factors and define the indicators. The fact that there are no international standards and regulations on pension system, makes is complicated to observe and benchmark the foreign experience in a standardized, uniform way.

Inefficiency of pension system causes improper material welfare for older people and uneven distribution of income in different age groups. This creates an uncertain economic environment and significantly increases social discontent. The ineffective pension system, alongside with social and economic fluctuations, has a major threat to political instability. Thus, the pension problem becomes political issue and the popularization of its study indicates the government's right priorities and the dominance of socially oriented development. The more socially oriented government is, the more importance it has to improve the pension system in the country's development strategy. It is, in some sense, a measure of democratic relations in the country. This approach puts the pension issue in the center of the interests of international structures, government and NGOs. A wide range of discussions is held at international forums and scientific meetings.

The aim of the presented research was to formulate a pension fund for Georgia in such a way that it reduces the financial burden of the state, and, at the same time, achieve the correct distribution of revenue and accumulation of material resources required for elderly people. Special 
attention was paid to the creation of a model of calculation of the optimal retirement age and gender structure of a pension fund for developing economies.

The generalizable results of this research can enrich the economic literature. However, the research outcomes also provide practical recommendations to the legislative and executive government of the country on pension reform policy and implementation process. Last, the Georgian example can be helpful for other developing economies planning to undergo the similar reforms.

\section{References}

Anderson, S. and Pratt D. 2016. "Pension and Employee Benefit Statutes and Regulations: Selected Sections" (Selected Statutes). Pillar Pensions.

Arnberg, S. and Barslund M. 2012. "The Crowding-Out Effect of Mandatory Labour Market Pension Schemes on Private Savings: Evidence from Renters in Denmark." Working Paper.

Bijak, J. et al. 2007. "Population and labour force projections for 27 European countries, 2002-2052: impact of international migration on population ageing. ” European Jorunal of Population 23(1): 1-31.

Blanchet, D., Bozio, A., and Rabaté, S. 2016. "Quelles options pour réduire la dépendance à la croissance du système de retraite français?" Revue Economique 67: 879-911.

Bovenberg, A. L. and Nijman, Th. E. 2017. "Personal pension ns with risk sharing." Journal of Pension Economics and Finance 16(4): 450-466.

Cipriani, G. P. 2018. “Aging, retirement and pay-as-you-go pensions. Macroeconomic Dynamics.” 22: 1173-1183.

Devolder, P., and de Valeriola, S. 2018. "Pension design and risk sharing: mix solutions between DB and DC for public pension schemes." In Public Pension Systems. The Greatest Economic Challenge of the 21st Century. Verlag: Springer (forthcoming)

Hutsebaut, M. (2017) "Pension system reform in Georgia. Comments and Alternatives", Friedrich-Ebert-Stiftung publication, Tbilisi. International Monetary Fund. 2011. The Challenge of Public Pension Reform in Advanced and Emerging Economies. Washington D.C.: Fiscal Affairs Department.

Kingsley, D.E. 2015. "Aging and health care costs: Narrative versus reality." Poverty Public Policy 7(1): 3-21.

Kochskaemper, S. and Pimpertz, J. 2015. "Live Long and Prosper? Demographic Change and the Implications of Europe's Pensions Crisis." Wilfried Martens Centre for European Studies, Brussels p. 24. Available at https://www.martenscentre.eu/publications/live-long-and-prosper-demographic-change-and-europes-pensionscrisis.

Lee, R. and A. Mason. 2010. "Some macroeconomic aspects of global population aging.” Demography 47(1):S151-172.

Organisation for Economic Co-operation and Development. 2015c. Pensions at a Glance 2015: OECD and G20 indicators, OECD Publishing. Paris. Available at http://dx.doi.org/10.1787/pension_glance-2015-en.

Schwan, A., and Sail, E. 2013. "Assessing the Economic and Budgetary Impact of Linking Retirement Ages and Pension Benefits to Increases in Longevity.” Brussels: European Commission: European Economy Economic Papers.

Tabatadze, M. 2016a. "Macroprudential regulation as a new methodology for macroeconomic policy makers." International Scientific And Practical Conference World Science 3(4): 24-28. Available at https://elibrary.ru/item.asp?id=25821857

Tabatadze, M. 2016b. "Mecanismes Of Taxation Optimisation In Transit Economy." International Scientific And Practical Conference World Science 4(8): 40-45. Available at https://elibrary.ru/item.asp?id=26500563

Tkemaladze I. 2016a. "Pension provision system in Georgia, reality and key challenges." Annual Reports of Paata Gugushvili Institute of Economics.

Tkemaladze I. 2016b. "Accrues pension system introduction prospective in Georgia." Conference proceedings "Challenges of Globalization in Economics and Business.

World Bank. 2016. "Pension reform in Georgia." 